SABRAO Journal of Breeding and Genetics

53 (4) 543-560, 2021

http://doi.org/10.54910/sabrao2021.53.4.1

http://sabraojournal.org/

pISSN 1029-7073; eISSN 2224-8978

\title{
BIOCHEMICAL AND CYTOLOGICAL FEATURES OF ONION BULBS AND LEAVES COLLECTED FROM VARIOUS ECOGEOGRAPHICAL ORIGINS
}

\author{
V.I. NEMTINOV ${ }^{1}$, Y.N. KOSTANCHUK ${ }^{1}$, V. S. PASHTETSKIY ${ }^{1}$, \\ S.M. MOTYLEVA ${ }^{2 *}$, A.I. BOKHAN ${ }^{2}$, G. CARUSO ${ }^{3}$, A.G. KATSKAYA ${ }^{1}$, \\ L.A. TIMASHEVA ${ }^{1}$ and O.A. PEKHOVA ${ }^{1}$
}

\footnotetext{
${ }^{1}$ Federal State Budget Scientific Institution "Research Institute of Agriculture of Crimea", Russia

${ }^{2}$ Federal Horticultural Center for Breeding, Agrotechnology and Nursery, Moscow, Russia

${ }^{3}$ Department of Agricultural Sciences, University of Naples, Naples, Italy

*Corresponding author email: motyleva_svetlana@mail.ru

Email addresses of co-authors: nemtinov@mail.ru, kostanchuk_yu@niishk.ru, pvs98a@gmail.com, alexboxan1980@mail.ru,gcaruso@unina.it, kackaja_a@niishk.ru, isocrimea@gmail.com, socrimea@gmail.com
}

\section{SUMMARY}

Allium cepa L. genotypes with different ecogeographical origins revealed the highest nutritional values when grown in Crimea, Russia. However, their environmental adaptation should be further investigated. This research was performed during 2016-17 to evaluate the qualitative, antioxidant, and mineral composition characteristics of 15 onion genotypes, of which four originated from the Federal State Budget Scientific Institution, Research Institute of Agriculture, Crimea, Russia. Sweet onion genotypes exhibited high ascorbic acid contents of $11.8-27.3 \mathrm{mg} / 100 \mathrm{~g}$. However, some genotypes had a narrow range of ascorbic acid content $(11.8-21.1 \mathrm{mg} / 100 \mathrm{~g})$ due to their different ecogeographical origins and proved to be appropriate for industrial processing because of their spicy taste. Intensely colored bulbs had a high content of polyphenols (anthocyanins), which are known to have a positive influence on human health. Electronic microscopic assays revealed the morphological characteristics of $A$. cepa $\mathrm{L}$. genotype leaves and demonstrated the differences in epidermal structure and adaptability potential. The 12 main mineral macro- and microelements with the highest contents in onion leaves were analyzed. The hyperaccumulator genotype with the highest leaf macro- and microelement content could be used to address mineral element deficiencies in humans. In onion genotype leaves, the contents of the mineral elements followed the order of $\mathrm{Zn}>\mathrm{Fe}>\mathrm{Si}>\mathrm{Na}>\mathrm{P}>\mathrm{Cl}>\mathrm{Mo}>\mathrm{Mg}>\mathrm{S}>\mathrm{Ca}>\mathrm{Cu}>\mathrm{K}$. The biochemical analysis of 13 onion cultivars showed that the majority exceeded the standard values of dry matter and sugars (mono- and disaccharides) by $13 \%$ and $46 \%, 11 \%$ and $48 \%$, and $36 \%$ and $150 \%$. In onion genotypes, leaf surface microstructure was specific, and the largest stomata corresponded to the most productive cultivars.

Keywords: Onion, bulb (Allium cepa L.), ascorbic acid, leaves, electronic microscopy scanning, energy dispersion $\mathrm{X}$-ray analysis, mineral elements

Key findings: $A$. cepa $\mathrm{L}$. samples with various ecogeographical origins exhibited the highest content of ascorbic acid and were found to be highly suitable for industrial processing due to their spicy taste. The 12 macro- and micromineral elements with the highest content in 
onion leaves were identified. The selected onion samples could be used in future breeding programs.

Manuscript received: June 16, 2021; Accepted: August 25, 2021.

(C) Society for the Advancement of Breeding Research in Asia and Oceania (SABRAO) 2021

Communicating Editor: Dr. Naqib Ullah Khan

\section{INTRODUCTION}

Plants naturally possess the capability to extract and assimilate mineral elements from the soil and water solutions. The macronutrients $\mathrm{N}, \mathrm{P}, \mathrm{S}, \mathrm{K}$, $\mathrm{Ca}, \mathrm{Mg}$, and $\mathrm{Fe}$ and the micronutrient $\mathrm{Cu}$, Mo, $\mathrm{Zn}, \mathrm{Mn}$, and $\mathrm{B}$ are necessary for plant growth and development. In addition to these nutrients, other useful elements, such as $\mathrm{Na}, \mathrm{Cl}$, and $\mathrm{Si}$, can be included. These elements are used in metabolic processes, and in their absence, the plant cannot progress through its whole development cycle. Green onion leaves are an excellent source of mineral elements that enter the human body in the form of ions in balanced concentrations. The soil and other multifactorial conditions that accompany onion growth affect the mineral composition of onions (Golubkina et al., 2009, 2015).

Onion is a major vegetable crop. It is actively used in the food and canning industry and modern medicine. Onions are consumed in a fresh, fried, or boiled form and are used in salads, minced meat, vegetable canning, and the meat and fish industry (Borisenkova, 1993; Vodyanova and Alpysbaeva, 2004). Green onion and garlic are recommended for the treatment or prophylaxis of the flu, atherosclerosis, and heart disease. In this case, onions suppress the synthesis of cholesterol and reduce the level of fibrinogen (a complex protein and glycoprotein of blood plasma, the most important component of blood clotting) (Galkin et al., 2000). Onions are a potential source of prostaglandins and substances that regulate blood pressure (Platonova, 2000; Agafonov et al., 2005). The plant flavonol quercetin, an important onion component, is used as a vasodilator in combination with vitamin C (Danikov, 1998; Ulyanova, 1998).

The biochemical composition of onion bulbs and green leaves varies depending on the cultivars and the environmental and agrotechnical conditions during plant growth (Ananyina and Glukhova, 1988; Kielak et al., 2006; Dudchenko, 2009). The German Society of Nutri-Sociologists (Deutsche Jesselschaft fur Ernahrung) presented the daily nutritional microelement requirement of human beings aged 25-51 years. Skurikhin and Tutelyan (2007) also reported on the varied values of nutritional elements in onion bulbs.

Most recent technologies that have been developed through physiological and medical research have confirmed the important role of micronutrients in metabolic reactions and submolecular processes. However, these activities depend on the presence of certain macroand micronutrient elements in the daily human diet (Avtsyn et al., 1991; Motyleva et al., 2017; Peter and Gandhi, 2017).

Given the lack of comparative data relevant to onion bulb biochemical properties and leaf anatomical and nutritional features, the current research was performed by using onion cultivars from nine countries grown under the environmental conditions of Crimea, Russia. In particular, the purpose of the present research was to measure the biochemical parameters of onion bulbs, as well as to determine the cytological features and consumer-influencing macroand micronutrient composition of the leaves of $15 A$. cepa $L$. genotypes with different ecogeographical origins. Among these 15 genotypes, 11 originated from nine diverse countries, and four were bred at the Federal State Budget Scientific 
Institution (FSBSI) Research Institute of Agriculture of Crimea (RIAC), Russia.

\section{MATERIALS AND METHODS}

\section{Plant growth conditions}

The present research was carried out during 2016-17 on $A$. cepa L. genotypes that were organically grown in the experimental fields at FSBSI 'RIAC', Russia. The studied soil was not contaminated with heavy metals and had the following characteristics: $4.5 \%-5.3 \%$ humus content, $6.3 \mathrm{mg} / 100 \mathrm{~g}$ mineral nitrogen $\left(\mathrm{N}-\mathrm{NO}_{3}\right), 18.4 \mathrm{mg} / 100 \mathrm{~g} \mathrm{P}_{2} \mathrm{O}_{5}$, $73.0 \mathrm{mg} / 100 \mathrm{~g} \mathrm{~K}_{2} \mathrm{O}$, and $\mathrm{pH}$ of 7.85 . The average temperature and rainfall for the 2 years of study were $17.5^{\circ} \mathrm{C}$ and $116 \mathrm{~mm}$ in May, respectively; $21.1{ }^{\circ} \mathrm{C}$ and 83.1 $\mathrm{mm}$ in June, respectively; and $25.3{ }^{\circ} \mathrm{C}$ and $53.7 \mathrm{~mm}$ in July, respectively.

\section{Experiment}

The experimental work comprised the assessment of 15 onion genotypes (nine with yellow bulbs, five with red-purple bulbs, and one with white bulbs) with different ecogeographical origins based on the biochemical parameters of the bulbs and the cytological and mineral values of the leaves. The genotypes were studied in the field in a randomized complete block design with four repetitions, and the experimental unit had a surface area of $1.5 \mathrm{~m}^{2}$.

The onion seedlings were transplanted into double rows on May 12. The rows were spaced $9 \mathrm{~cm}$ along and 25 $\mathrm{cm}$ apart. The outer rows of adjacent double-rows were spaced $40 \mathrm{~cm}$ apart. Organic fertilizers were applied at the ratio of 120:50:130 N, $\mathrm{P}_{2} \mathrm{O}_{5}$, and $\mathrm{K}_{2} \mathrm{O} \mathrm{kg} / \mathrm{ha}$ in compliance with the EU Regulation $834 / 2007$. The whole amounts of $P$ and $K$ and $50 \%$ of $\mathrm{N}$ were applied before transplantation by using Bioilsa 6-5-13 fertilizer, whereas the remaining $50 \%$ of $\mathrm{N}$ was supplied during the crop cycles in the form of $11 \% \mathrm{~N}$ fertilizer. Irrigation was activated when the soil water decreased to
$70 \%$ soil water capacity. The onion bulbs were harvested at maturity on August 0408 when $50 \%$ of the plants exhibited softened pseudostems and flattened leaves. After harvesting, the plants were left to cure in the field in windrows for 2 weeks.

\section{Chemical analyses}

The basic parameters of onion quality were determined via the following methods: dry solid-thermal gravimetric method; ascorbic acid-visual titration with Tillman's reagent; total sugars and reducing sugars-photocolorimetric method; and essential oil-distillation chromatographic method (Timasheva et al., 2018). All the analyses were repeated three times, and the results were expressed in the form of mean values \pm standard deviation. The statistics were processed in accordance with the standard methods by using the software package Microsoft Office 2013 (Microsoft, Inc., USA). $\mathrm{HCP}_{05}$ value (with $95 \%$ likelihood ratio) was used in dispersive analysis to compare the samples with the control and with one another.

\section{Electron microscopy investigation}

The morphological features of $A$. cepa $\mathrm{L}$. cultivar leaves were studied in the laboratory by using raster electron microscopy (REM). For REM investigation, leaf segments from the central part of the surface (in the second decade of June) with the dimensions of $5 \times 5 \mathrm{~mm}$ were placed on a special adhesive tape and set on the object table of REM JEOL JSM 6010-LA. The epidermis was studied from the abaxial side of the leaf in accordance with the applicable rules of REM.

\section{Sample preparation}

For the analysis of quantitative elemental composition, the onion leaf samples were mineralized in a muffle furnace (Naberterm, Germany) at $400{ }^{\circ} \mathrm{C}$. The received ash was dispersed by ultrasound at $18 \mathrm{kHz}$ for $15 \mathrm{~min}$. A dispersed even 
Nemtinov et al. (2021)

layer was applied on the object table covered with carbonic scotch.

\section{Energy dispersive spectrometry analysis}

The chemical composition of the basic ash components ( $\mathrm{K}, \mathrm{P}, \mathrm{Mg}, \mathrm{Ca}, \mathrm{Fe}, \mathrm{S}, \mathrm{Na}, \mathrm{Cl}$, $\mathrm{Cu}, \mathrm{Mo}, \mathrm{Zn}$, and $\mathrm{Si}$ ) was determined by energy dispersive spectrometry on the analytical raster electron microscope JEOL JSM 6090 LA. The microscope resolution was $4 \mathrm{~nm}$ at the accelerating voltage of 20 kV (secondary electron image). Zooming was performed from $10 \times$ to $10000 \times$. During elemental analysis, the working distance was $10 \mathrm{~mm}$. An energydispersive spectrometer enables quantitative $X$-ray microanalysis on the desired analysis area, i.e., in a point or area, and to acquire the maps of element allocation. X-ray microanalysis data were presented in the form of standard protocols that contained the microstructure picture of the samples under study, the table of the weight data and atomic correlation, spectra, and histograms.

\section{Statistical analyses}

A $2 \times 2 \times 3$ factorial design was employed. The data from the determination of the minerals were analyzed via analysis of variance by using the MSTAT-C statistical package (Michigan State University, East Lansing, USA), and the mean values were compared and separated through LSD test at $P \leq 0.05$. The relationship among the minerals was evaluated by using Pearson's productmoment correlation at $P \leq 0.05$. Principal component analysis was performed to determine the relationship among rootstock/cultivar combinations and the variables by using the princomp procedure of the SAS statistical package (SAS Institute Inc., North Carolina, USA). All the analyses were performed in triplicate. The results were expressed as mean values $(n=3)$ in standard deviation. Statistical analyses were conducted with the Excel package (Microsoft Excel, v. 2016).

\section{RESULTS AND DISCUSSION}

\section{Mineral composition of onion leaves}

Onion bulbs and young leaves are used as food. Green leaves have fewer dry solids and soluble carbohydrates than bulbs but contain a considerable amount of $\mathrm{N}$ compounds, minerals, and vitamins. In traditional medicine, the daily use of 100 $\mathrm{g}$ of green onion against hepatic and bile duct diseases is recommended. The role of microelements has not been fully investigated yet, and the recent data are controversial. Therefore, the 12 most important macro- and micronutrients in green onion leaves were analyzed. Seventeen trace elements were also found in the onion's ash. Microelements, such as $\mathrm{Cu}, \mathrm{Zn}, \mathrm{Co}$, and Mo, are part of enzymes and participate in their activation, thus improving plant growth and development.

$K$ is necessary for muscle contractions, heart muscle normalization, nerve cell activity, blood osmotic concentration, acid-alkaline balance, and water balance. It controls the transmembrane potential of osmotic pressure, the cation-anion balance, and the $\mathrm{pH}$ of cell hemostasis. In ion form, $\mathrm{K}$ increases the concentration of other ions and is found in all organs of the human body (Meathnis et al., 1997). The highest value of $\mathrm{K}(20 \%$ to $31 \%)$ was found in the leaves of nine onion genotypes (Figure 1 ). The highest $\mathrm{K}$ content ( $20 \%$ to $30.3 \%$ ) of onions or green onion leaf feathers provides $52 \%-81 \%$ of a person's daily nutrient requirement at the rate of 175 and $259 \mathrm{mg}$ per $100 \mathrm{~g}$ of nutrients (WHO, 2012).

The leaves of five onion cultivars with different origins contained a moderate amount of $\mathrm{K}(10.6 \%$ to $16.8 \%)$, and 'Yaltinskiy Model No.3' (Russia) had a $\mathrm{K}$ content of only $6.7 \%$ (Figure 1 ). Chope and Terry (2009) found a similar potassium content in the onion cultivar 


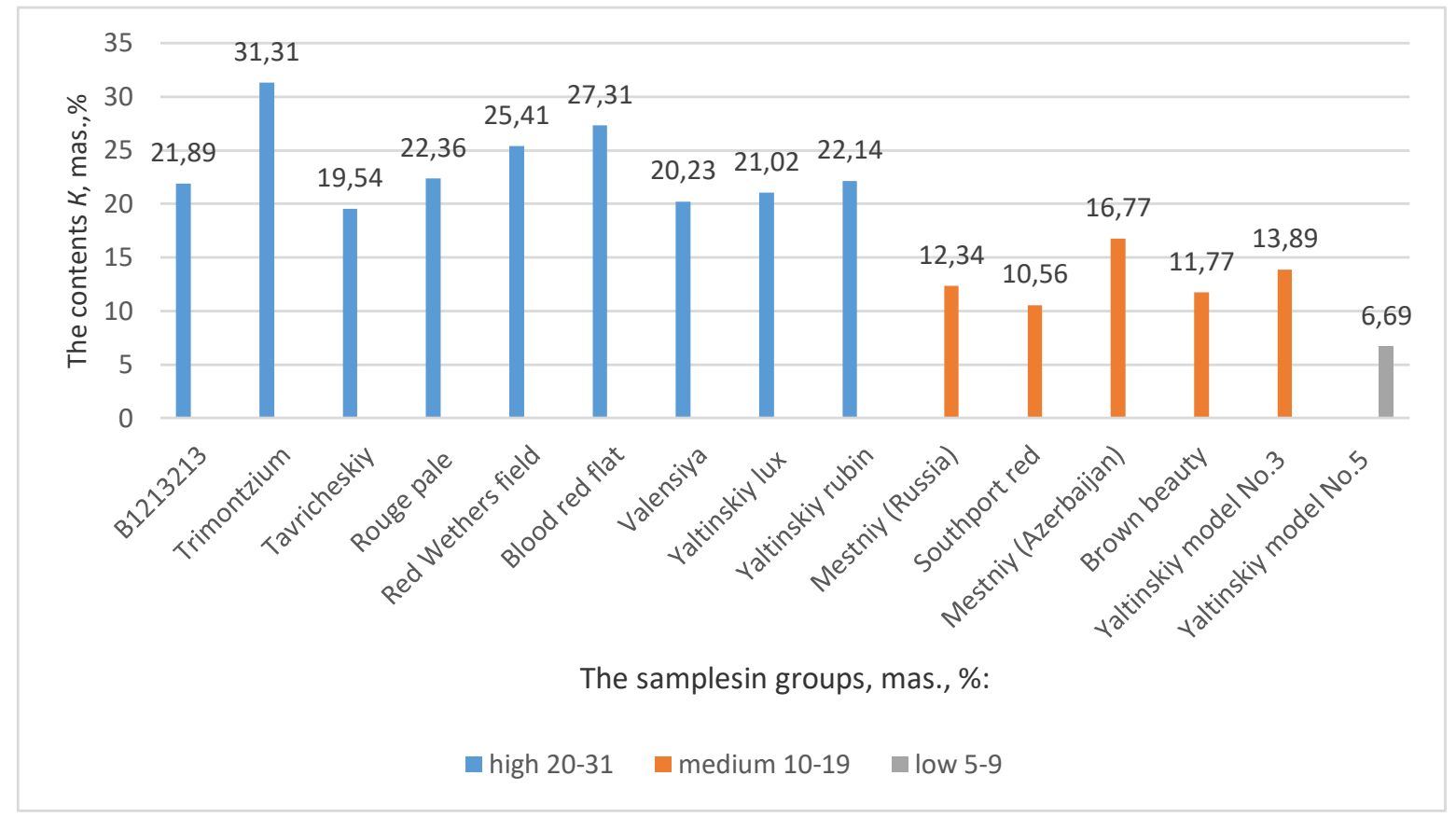

Figure 1. Varietal differences in $\mathrm{K}$ accumulation in $A$. cepa L. genotype leaves.

'SS1' (on average $14.9 \mathrm{~g} \mathrm{k} / \mathrm{kg} \mathrm{DM}$ ). K showed medium correlation values with $\mathrm{Mg}, \mathrm{Cl}, \mathrm{S}$, and $\mathrm{Cu}(r=0.4-0.6)$; a high correlation with Mo $(r=0.7)$, and low correlations with $\mathrm{Na}, \mathrm{Ca}$, and $\mathrm{Zn}(r=0.16$ to 0.24). The present results were consistent with the past findings, which revealed that $\mathrm{K}$ had average values of correlation with $\mathrm{Mg}, \mathrm{P}$, and $\mathrm{Ca}(r=0.3-$ $0.5)$ and very low correlation values with $\mathrm{Zn}$ and $\mathrm{Cu}(r=0.2--0.1)$ (Seridin et al., 2017).

$P$ is part of human and animal skeletons, and more than $50 \%$ of $P$ is found in the tissues in the form of inorganic compounds. It represents an integral part of DNA, RNA, phospholipids, $A T F$, and ADP, where it executes a structural function and has a primary role in cellular energy. The greatest $P$ content was detected in the leaf ash of six onion genotypes i.e., 'Blood Red Flat' (the Netherlands), 'B1213213' (Australia), 'Mestniy' (Azerbaijan), 'Valensiya' (Portugal), 'Yaltinskiy Lux,' and 'Yaltinskiy Rubin' (Russia) (Figure 2). Moderate $P$ contents $(1.2 \%$ to $1.4 \%$ of weight) were found in three onion genotypes, i.e.,
'Trimontzium' (Bulgaria), 'Yaltinskiy Model No.3' (Russia), and 'Rouge Pale' (Algeria). A low concentration of $P(0.4 \%$ to $0.7 \%$ of weight) was found in five onion samples, i.e., 'Mestniy' (Russia), 'Southport Red' (USA), 'Red Wethers Field' (Bolivia), 'Brown Beauty' (USA), and 'Yaltinskiy model No.5' (Russia). A very low value of $P(0.22 \%$ of weight) was found in the onion genotype 'Tavricheskiy' (Russia). $P$ had a moderate relationship with other elements, i.e., S, K, Fe, and Mo ( $r=0.3-$ $0.6)$ and a nonsignificant correlation with $\mathrm{Ca}(r=0.2), \mathrm{Cl}, \mathrm{Cu}$, and $\mathrm{Zn}(r=0.01-$ $0.02)$. Similar $P$ contents and correlations with other elements in onions were also reported by Rodriges et al. (2008).

$\mathrm{Mg}$ is necessary for Ca absorption; the metabolism of glucose, amino acids, and fats; and the transportation of nutrients. It is also involved in protein synthesis and nerve signal transmission. It also plays an important role in the regeneration of cells, tissues, and other organs. $\mathrm{Mg}$ also activates a large number of enzymes that are involved in $\mathrm{CO}_{2}$ and $\mathrm{N}$ consumption. The highest value of $\mathrm{Mg}$ $(2.23 \%$ of weight) was found in the leaf 


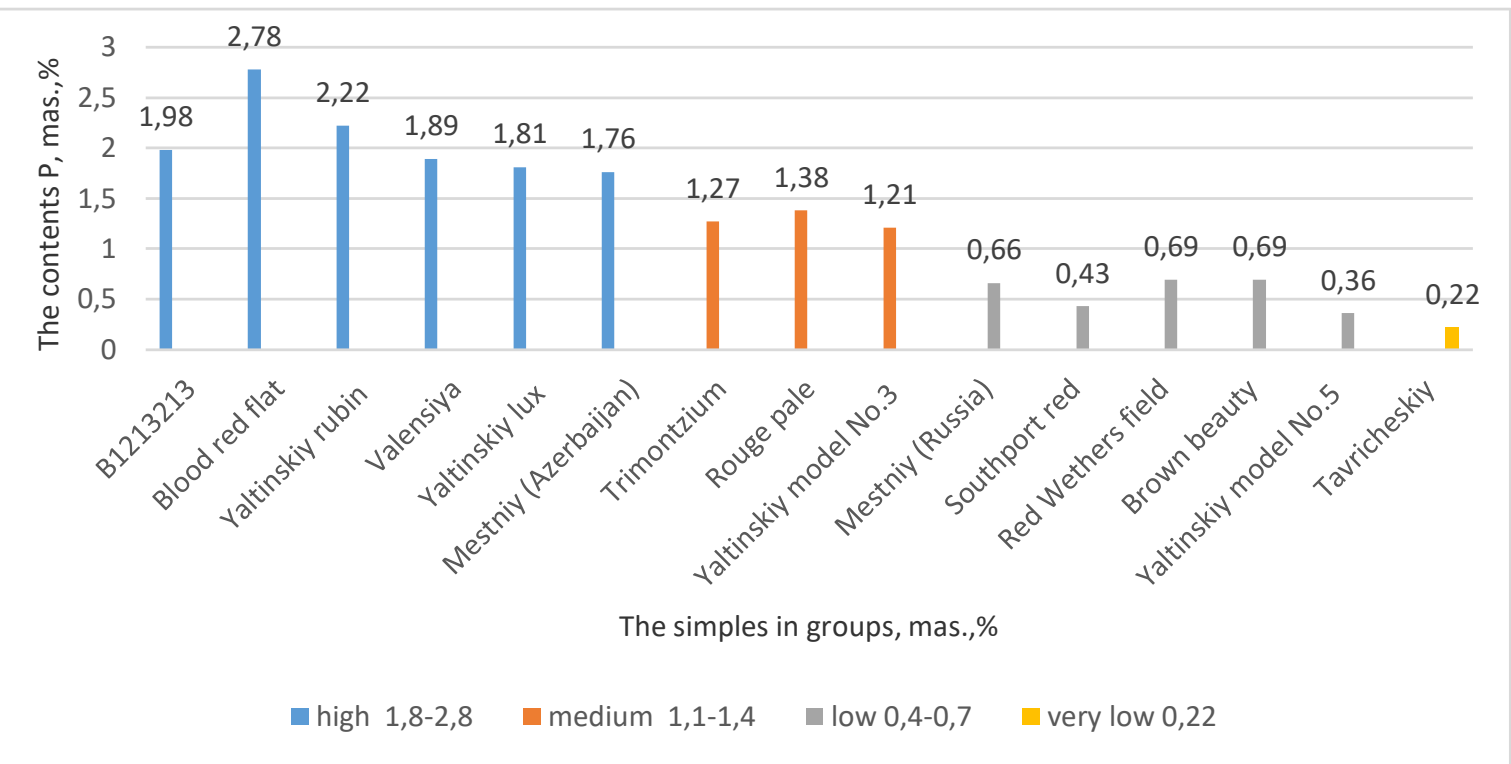

Figure 2. Varietal differences in $\mathrm{P}$ accumulation in $A$. cepa L. genotype leaves.

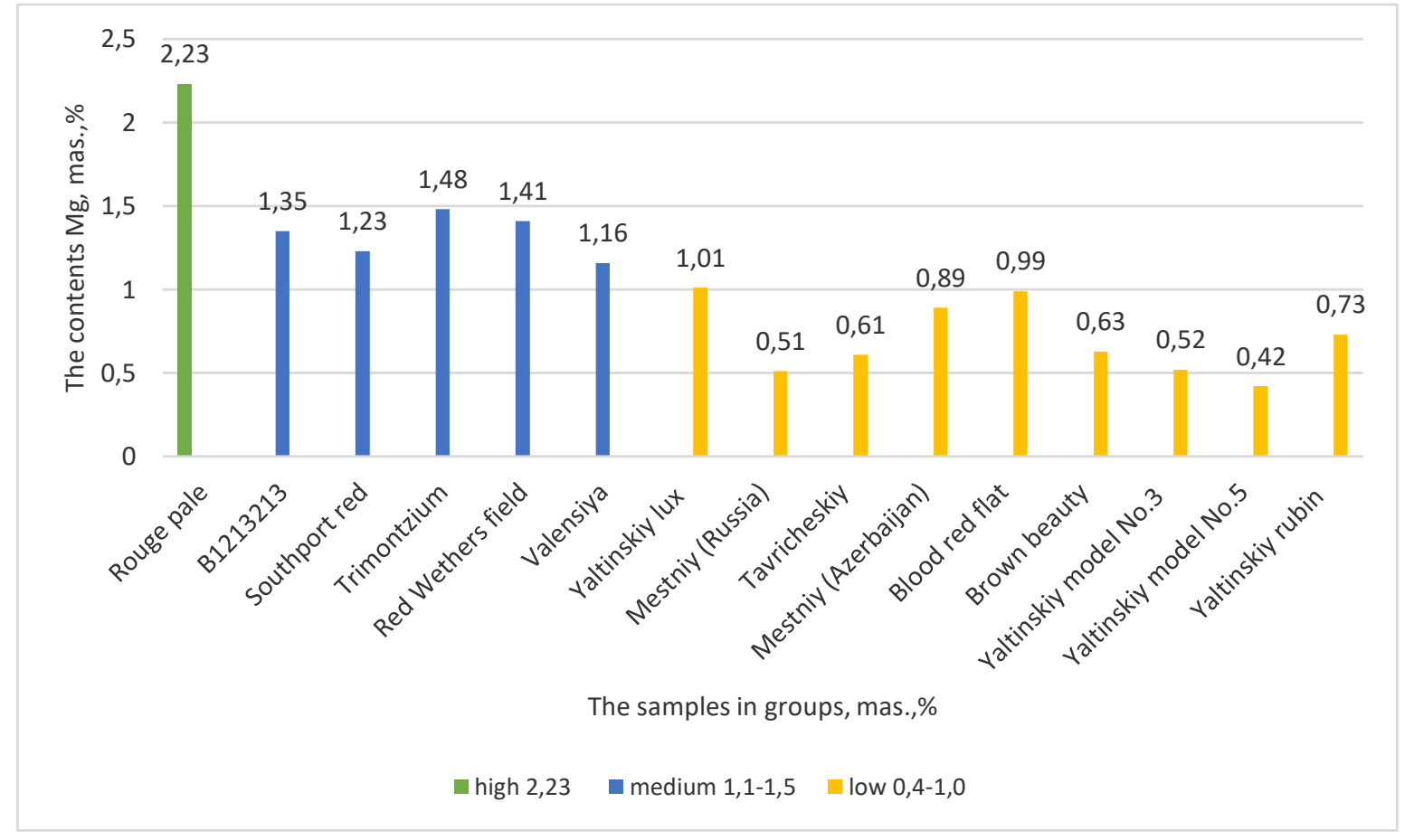

Figure 3. Varietal differences in $\mathrm{Mg}$ accumulation in $A$. cepa $\mathrm{L}$. genotype leaves. 
sample of 'Rouge Pale' (Algeria), whereas moderate ratios ( $1.1 \%$ to $1.5 \%$ of weight) were detected in five other onion genotypes, i.e., 'B1213213B' (Australia), 'Southport Red' (USA), 'Trimontzium' (Bulgaria), 'Red Wethers Field' (Bolivia), and 'Valensiya' (Portugal) (Figure 3). A low $\mathrm{Mg}$ value $(0.4 \%$ to $1.0 \%$ of weight) was recorded in nine onion genotypes, i.e., 'Mestniy' (Russia), 'Tavricheskiy' (Russia), 'Mestniy' (Azerbaijan), 'Blood Red Flat' (the Netherlands), and 'Brown Beauty'(USA) and four onion samples from FSBSI-RIA, Crimea Russia, i.e., 'Yaltinskiy Model No.3', 'Yaltinskiy Model No.5', 'Yaltinskiy Lux', and 'Yaltinskiy Rubin'.

The observed minimum Mg content $(0.42 \%-0.79 \%)$ in the leaves of the onion varieties 'Mestniy', 'Tavricheskiy', 'Brown Beauty', 'Yaltinskiy Model No.3', 'Yaltinskiy Model No.5', and 'Yaltinskiy Rubin' supported the past findings of Goolong et al. (2004), who obtained similar results in the analysis of the onion variety 'Valencia'. However, average Mg contents were found in 'Valencia' grown in Crimea. The present results were consistent with the opinion that onion crop quality depends on growing conditions (Randle, 2000; Błażewicz-Woźniak et al., 2008; Jurgiel-Małecka and Suchorska-Orłowska, 2008; Kalbarczyk and Kalbarczyk, 2015). $\mathrm{Mg}$ had moderate correlations with $\mathrm{K}, \mathrm{Ca}$, and $\mathrm{Zn}(r=0.3-0.6)$, and nonsignificant correlations with $\mathrm{Si}, \mathrm{P}, \mathrm{S}, \mathrm{Cl}, \mathrm{Fe}$, and $\mathrm{Cu}(r$ $=0.08-0.22$ ). Seredin et al. (2017) reported that in winter garlic bulbs, $\mathrm{Mg}$ has an average correlation with $\mathrm{Fe}$ and $\mathrm{Zn}$ $(r=0.4-0.5)$ and an insignificant association with Si $(r=0.02)$.

The major part of the human skeleton and teeth consists of $\mathrm{Ca}$, which is involved in cell growth and development and affects enzymes, metabolism, and immunity (Gins and Gins, 2011). In onion bulbs, Ca concentrations were higher than $P$ concentrations (Yunus, 2016). In onion leaf ash, $\mathrm{Ca}$ was found at high rates ( $5.43 \%$ to $8.27 \%$ of weight) in nine onion genotype samples, i.e., 'Mestniy' (Russia), 'Rouge Pale' (Algeria), 'Mestniy' (Azerbaijan), 'Red Wethers Field (Bolivia),
'Blood Red Flat' (the Netherlands), 'Valensiya' (Portugal), 'Brown Beauty' (USA), and two cultivars from FSBSI RIA of Crimea, Russia, i.e., 'Yaltinskiy Lux', and 'Yaltinskiy Rubin' (Figure 4). Six genotype samples showed a medium ratio $(3.74 \%$ to $4.92 \%$ of weight) i.e., 'Yaltinskiy Model No.5' (Russia), 'B1213213' (Australia), 'Southport Red' (USA), 'Trimontzium' (Bulgaria), 'Tavricheskiy' (Russia), and 'Yaltinskiy Model No.3' (Russia). Ca was correlated with Mo $(r=0.3)$, as well as with $\mathrm{Fe}, \mathrm{Cu}$, and $\mathrm{Zn}(r=0.06-0.13)$. Fluctuations in $\mathrm{Fe}$ accumulation were associated with interdependent factors i.e., geographical, hormonal, and soil types, where a strong correlation between Fe and $\mathrm{Mn}(0.94 ; P<$ 0.001 ) was found (Kabata-Pendias, 2001; Golubkina et al., 2015, 2016). The micronutrient contents obtained in this study were in line with the findings of Chope and Terry (2009) and Kleiber et al. (2010) and slightly higher than those reported by Rodrigues et al. (2008).

$\mathrm{Fe}$ is the core active element of the blood hemoglobin and other cell enzymes. Moreover, it catalyzes breathing processes. Organic $\mathrm{Fe}$ is an important compound of the body and a part of numerous oxidation-reduction enzymes. The leaf ash of the two onion cultivars 'B1213213' (Australia) and 'Tavricheskiy' (Russia) showed increased $\mathrm{Fe}$ accumulation $(0.49 \%$ to $0.78 \%$ of weight). Moderate $\mathrm{Fe}$ accumulation $(0.11 \%$ to $0.21 \%$ of weight) was shown by the other nine onion genotypes, i.e., 'Mestniy' (Russia), 'Trimontzium' (Bulgaria), 'Rouge Pale' (Algeria), Blood Red Flat' (the Netherlands), 'Red Wethers Field' (Bolivia), 'Valensiya' (Portugal), and 'Brown Beauty' (USA), and two cultivars from Crimea, Russia, i.e., 'Yaltinskiy Lux' and 'Yaltinskiy Rubin'. A low Fe content ( $0.06 \%$ to $0.08 \%$ of weight) was found in four onion genotypes i.e., 'B1213213' (Australia), 'Mestniy' (Azerbaijan), 'Yaltinskiy Model No.3', and 'Yaltinskiy Model No.5' (Russia). Yoldas et al. (2011) also reported low Fe contents in the ash of onion genotypes. 


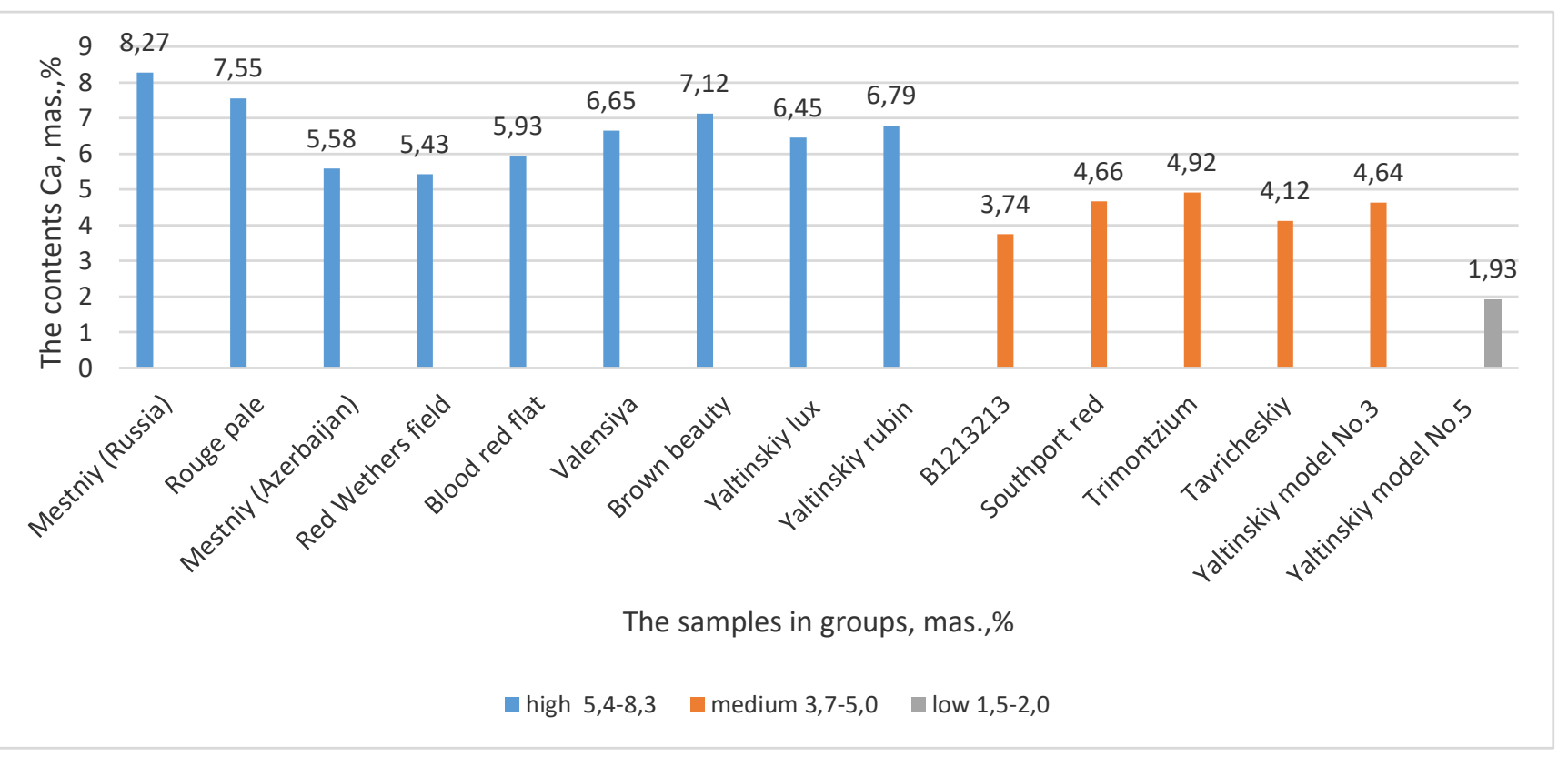

Figure 4. Varietal differences in Ca accumulation in A. cepa L. genotype leaves.

In living organisms, $S$ regulates protein synthesis, quantity, and quality and has antioxidant activity. It ensures electron energy transfer in the cells. It participates in the transportation and fixation of methyl groups and in the production of various hydrogen compounds, which allow the transmission of genetic information (Gins et al., 2018). The highest S content ( 2.08 mas\% to 2.5 mas.\%) was found in seven onion genotypes, i.e., 'B1213213' (Australia), 'Tavricheskiy' (Russia), 'Mestniy' (Azerbaijan), 'Red Wethers Field' (Bolivia), 'Yaltinskiy Model No.3', 'Yaltinskiy Lux', and 'Yaltinskiy Rubin' (Russia). A moderate $S$ content (1.3-1.5 mas.,\%) was noted in four onion cultivars, i.e., 'Trimontzium' (Bulgaria), 'Rouge Pale' (Algeria), 'Blood Red Flat' (the Netherlands), and 'Valensiya' (Portugal). The four other onion samples, i.e., 'Mestniy' (Russia), 'Brown Beauty'(USA), 'Southport Red' (USA), and 'Yaltinskiy Model No.5' (Russia) were characterized by low $S$ content (0.6-0.8 mas., \%) (Figure 5). Correlation analysis revealed a moderate relationship between $\mathrm{S}$ and $\mathrm{Cl}(r$
$=0.3)$ and a low correlation $(r=0.08$ to 0.21 ) with other macro- and micronutrient elements ( $\mathrm{Ca}, \mathrm{Fe}, \mathrm{Cu}$, and $\mathrm{Zn}$ ). The $\mathrm{S}$ content of the onion varieties in this study corresponded well to the values found in past studies (Jurgiel-Małecka, SuchorskaOrłowska, 2008; Chope and Terry, 2009; Kleiber et al., 2010).

$\mathrm{Na}$ is a part of the plant enchylema that creates high osmotic pressure and is found mainly in intercellular fluid. $\mathrm{Na}$ in combination with $\mathrm{K}$ is involved in membrane potential creation, enzyme and muscle contractions, and acid-alkaline and water balance activation, as well as enables transmembrane transfer (Avtsyn et al., 1991). Na accumulation was high ( $1.28 \%$ to $1.47 \%$ of weight) in 'Mestniy' (Russia) and 'B1213213' (Australia) and moderate $(0.5 \%$ to $0.9 \%$ of weight) in six onion genotypes, i.e., 'Trimontzium' (Bulgaria), 'Rouge Pale' (Algeria), 'Mestniy' (Azerbaijan), 'Red Wethers Field (Bolivia), 'Blood Red Flat' (the Netherlands), and 'Brown Beauty'(USA) (Figure 6). The other seven onion cultivars showed low values of $\mathrm{Na}$. $\mathrm{Na}$ had a moderate correlation with $\mathrm{Cl}$ and $\mathrm{Fe}(r=$ 


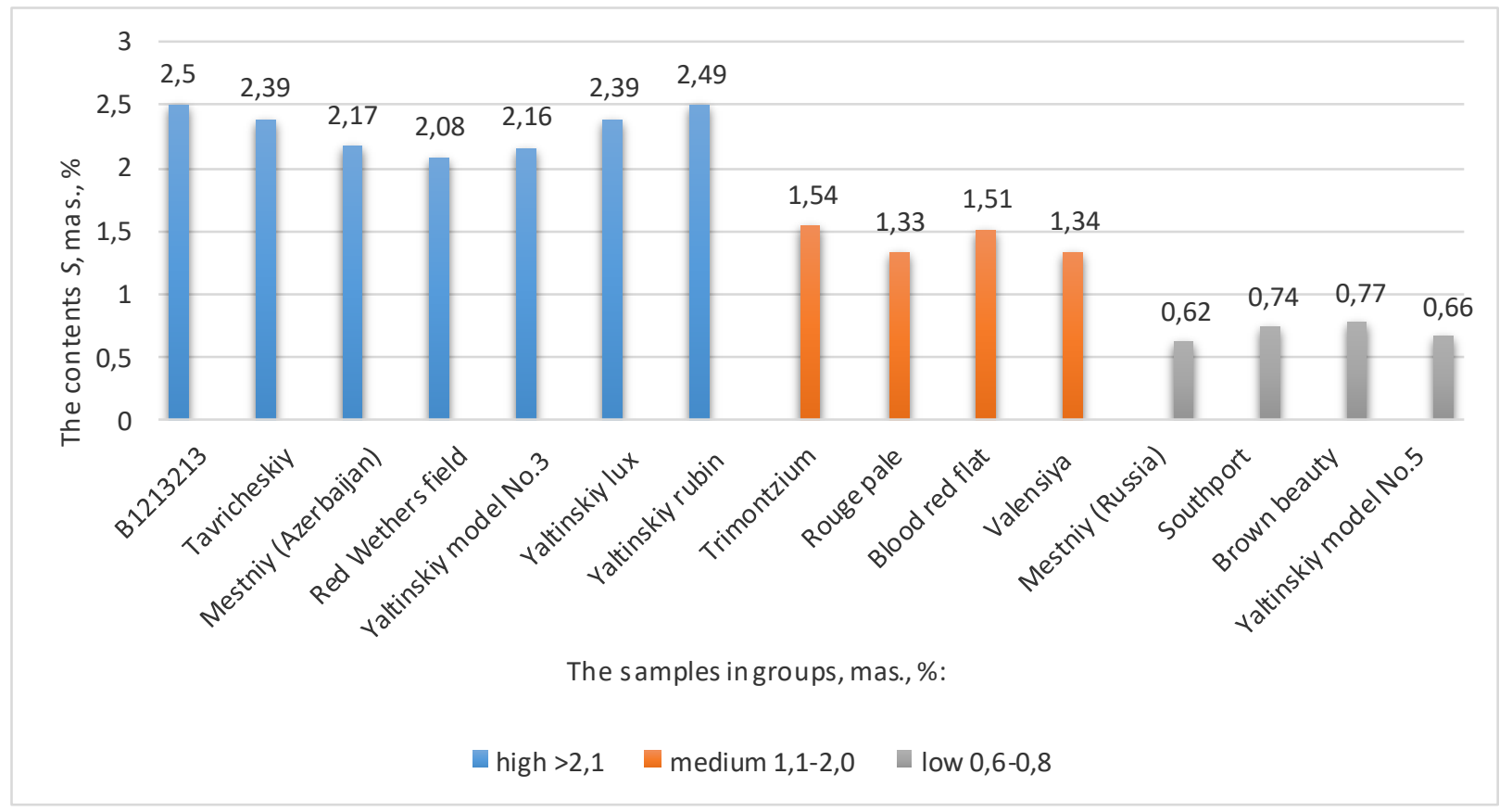

Figure 5. Varietal differences in $\mathrm{S}$ accumulation in A. cepa L. genotype leaves.

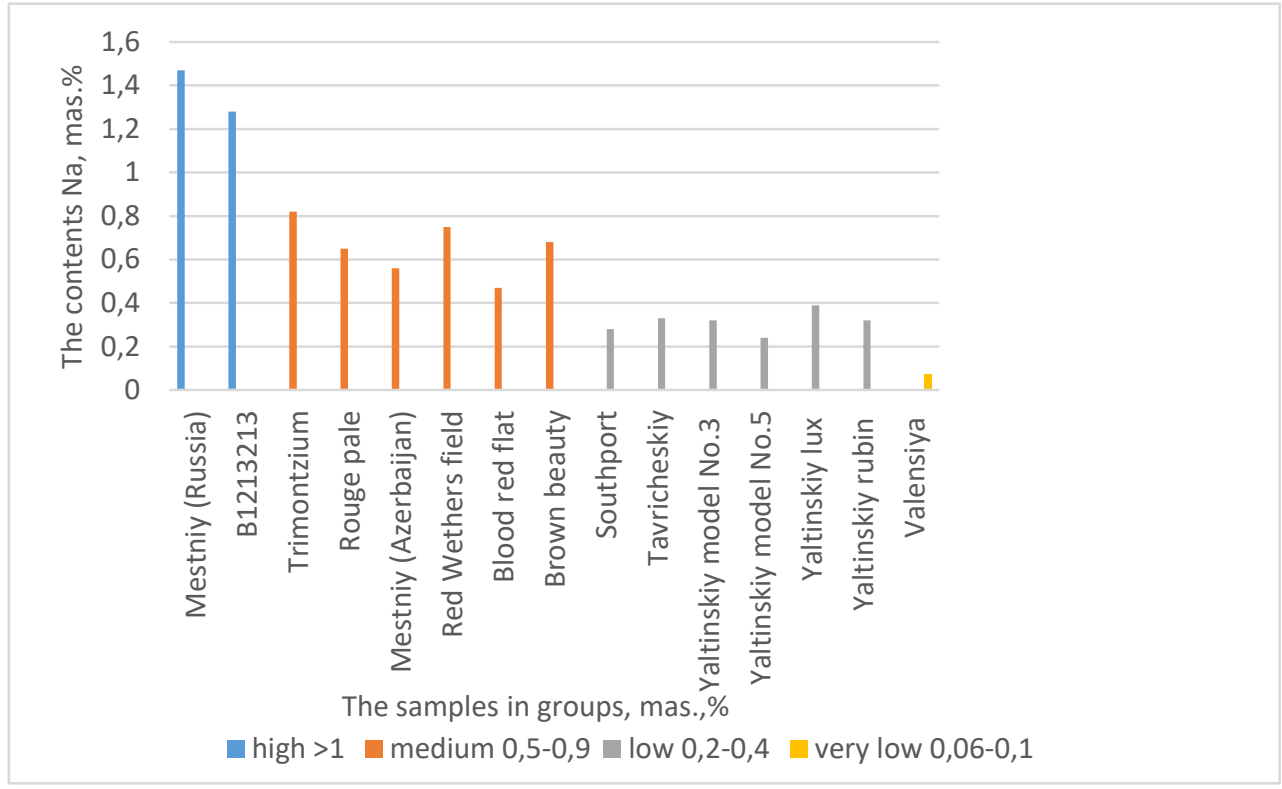

Figure 6. Varietal differences in $\mathrm{Na}$ accumulation in $A$. cepa L. genotype leaves. 


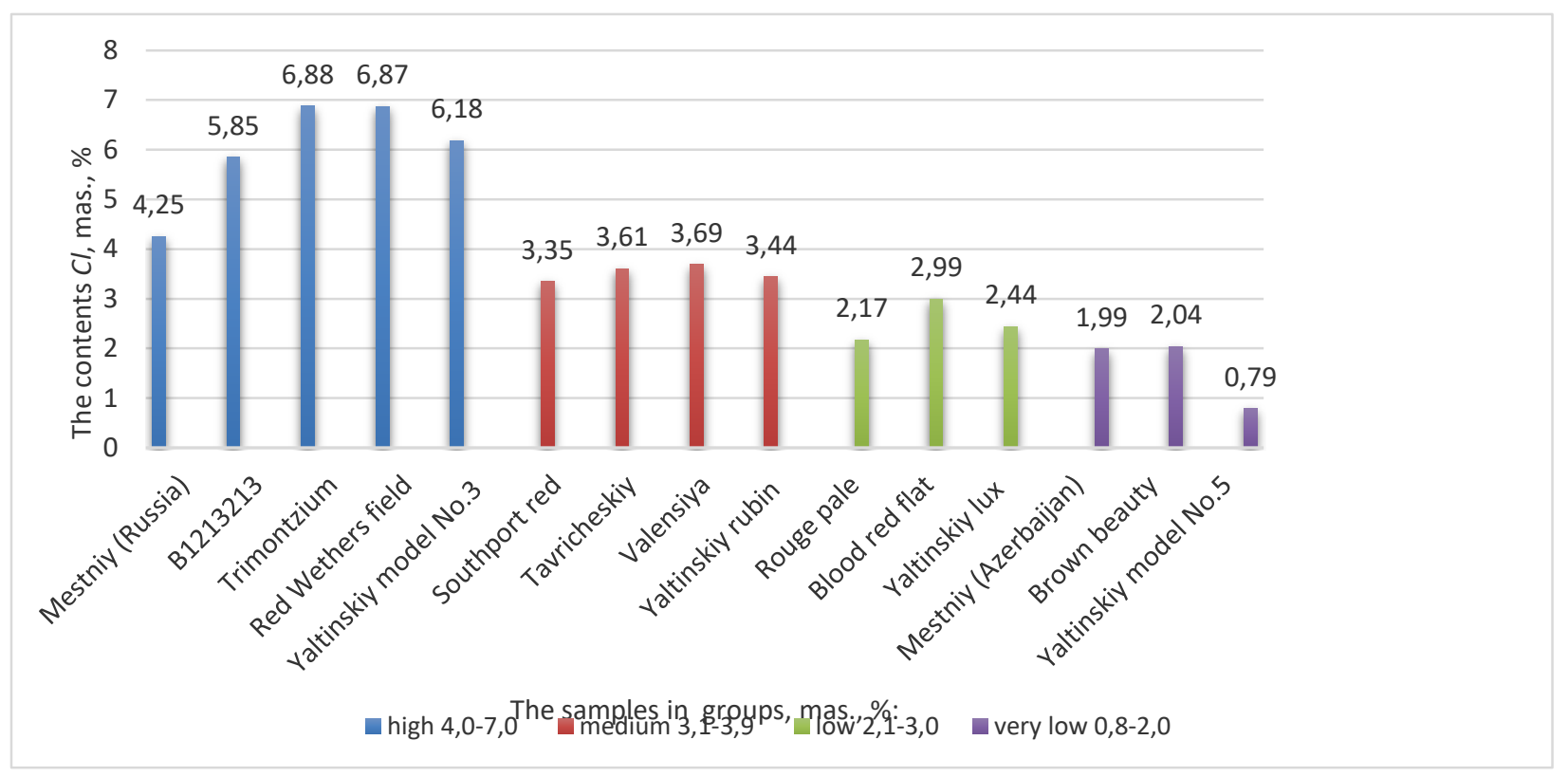

Figure 7. Varietal differences in $\mathrm{Cl}$ accumulation in $A$. cepa L. genotype leaves.

0.49 and 0.28 , respectively), and low ( $r=$ 0.12 to 0.25$)$ and very low $(r=0.06$ to $0.08)$ correlations with all other elements. No past findings have revealed the correlation among $\mathrm{Na}, \mathrm{Cl}$, and $\mathrm{Fe}$ in onions; the role of these elements in human nutrition has been emphasized by Tosin et al. (2017).

$\mathrm{Cl}$ is one of the biogenic elements and is a constant component of plant, human, and animal tissues. $\mathrm{Cl}$ ions in combination with $\mathrm{Na}$ and $\mathrm{K}$ are involved in osmotic equilibrium maintenance and acid-alkaline equilibrium regulation. $\mathrm{NaCl}$ plays an important role in chemical composition and water-salt exchange maintenance in the tissues. $\mathrm{Cl}$ is also an integral part of hydrochloric acid in gastric juice and actively affects digestion. $\mathrm{Cl}$ content was high $(4.25 \%$ to $6.88 \%$ of weight) in the leaves of five onion genotypes, i.e., 'Mestniy' (Russia), 'B1213213' (Australia), 'Trimontzium' (Bulgaria), 'Red Wethers Field' (Bolivia), and 'Yaltinskiy Model No.3' (Russia); moderate $(3.44 \%$ to $3.69 \%$ of weight) in three genotypes, i.e., 'Southport Red' (USA), 'Tavricheskiy' (Russia), and
'Valensiya' (Portugal); and low in four other cultivars $(1.99 \%$ to $2.99 \%$ of weight) (Figure 7). Cl plays an important role in cell activities and regulates the movement of stomata (Schoenbl and Ziegler, 1977; Díaz-Pérez et al., 2018).

$\mathrm{Cu}$ is an essential micronutrient with an important role in the metabolism of humans and mammals (Avtsyn et al., 1991). It is also connected to enzymes, hormones, and vitamins (Fraga, 2005). The U.S. Institute of Medicine and the European Union's Food Science Committee state that the daily $\mathrm{Cu}$ requirement of an adult human is $1-1.5 \mathrm{mg}$. $\mathrm{Cu}$ is involved in the biological mechanisms of enzyme biocatalysis, electron transfer, and interaction with $\mathrm{Fe}$. It participates in organ generation and hemoglobin formation, growth, and development. The importance of onions as a source of $\mathrm{Fe}, \mathrm{Mn}$, and $\mathrm{Cu}$ has been enhanced (Skalnaya et al., 2004; Golubkina et al., 2013). The highest $\mathrm{Cu}$ content was found in one onion cultivar 'Yaltinskiy Model No.5' from Russia ( $1.93 \%$ of weight) (Table 1 ). A moderate amount of $\mathrm{Cu}(1.0 \%$ to $1.5 \%$ of weight) was found in eight other onion cultivars, 
Table 1. Varietal differences in $\mathrm{Cu}, \mathrm{Mo}, \mathrm{Zn}$, and $\mathrm{Si}$ accumulation in $A$. cepa L. genotype leaves.

\begin{tabular}{lllll}
\hline Onion genotypes & $\mathrm{Cu}$ & $\mathrm{Mo}$ & $\mathrm{Zn}$ & $\mathrm{Si}$ \\
\hline Mestniy (Russia) & $1.11 \pm 0.14$ & $1.86 \pm 0.33$ & $0.49 \pm 0.45$ & $0.06 \pm 0.12$ \\
B1213213 (Australia) & $1.09 \pm 0.06$ & $6.14 \pm 0.04$ & $0.58 \pm 0.51$ & $0.24 \pm 0.04$ \\
Southport red (USA) & $0.88 \pm 0.11$ & $1.73 \pm 0.93$ & $0.28 \pm 0.11$ & $0.034 \pm 0.11$ \\
Trimontzium (Bulgaria) & $1.06 \pm 0.15$ & $5.52 \pm 0.64$ & $0.22 \pm 0.21$ & $0.14 \pm 0.06$ \\
Tavricheskiy (Russia) & $1.23 \pm 0.11$ & $6.83 \pm 0.81$ & $0.11 \pm 0.22$ & $0.07 \pm 0.08$ \\
Rouge pale (Algeria) & $0.69 \pm 0.21$ & $3.54 \pm 0.62$ & $0.65 \pm 0.22$ & $0.07 \pm 0.06$ \\
Mestniy (Azerbaijan) & $1.11 \pm 0.11$ & $5.49 \pm 0.64$ & $0.22 \pm 0.22$ & $0.29 \pm 0.08$ \\
Red Wethers Field (Bolivia) & $0.12 \pm 0.20$ & $5.59 \pm 0.83$ & $0.2 \pm 0.11$ & $0.12 \pm 0.06$ \\
Blood Red Flat (Netherlands) & $0.88 \pm 0.31$ & $2.68 \pm 1.24$ & $0.47 \pm 0.34$ & $0.08 \pm 0.07$ \\
Valensiya (Portugal) & $1.41 \pm 0.20$ & $4.01 \pm 0.64$ & $0.07 \pm 0.09$ & $0.13 \pm 0.04$ \\
Brown Beauty (USA) & $0.89 \pm 0.42$ & $1.35 \pm 0.32$ & $0.68 \pm 0.11$ & $0.09 \pm 0.22$ \\
Yaltinskiy Model No.3 (Russia) & $0.77 \pm 0.21$ & $5.15 \pm 0.82$ & $4.97 \pm 0.11$ & $0.29 \pm 0.11$ \\
Yaltinskiy Model No.5 (Russia) & $1.93 \pm 0.64$ & $0.44 \pm 0.24$ & $0.33 \pm 0.11$ & $0.15 \pm 0.06$ \\
Yaltinskiy Lux (Russia) & $1.15 \pm 0.84$ & $5.88 \pm 2.54$ & $0.31 \pm 0.11$ & $0.51 \pm 0.25$ \\
Yaltinskiy Rubin (Russia) & $1.32 \pm 0.40$ & $5.42 \pm 0.45$ & $0.82 \pm 0.13$ & $0.06 \pm 0.12$ \\
\hline
\end{tabular}

i.e., 'Mestniy' (Russia), 'B1213213' (Australia), 'Trimontzium' (Bulgaria), 'Tavricheskiy' (Russia), 'Mestniy' (Azerbaijan), and 'Valensiya' (Portugal) and in two cultivars from Russia, i.e., 'Yaltinskiy Lux' and 'Yaltinskiy Rubin'. Low $\mathrm{Cu}$ accumulation ( $0.12 \%$ to $0.9 \%$ weight) was recorded in six onion genotypes, i.e., 'Southport Red' (USA), 'Rouge Pale' (Algeria), 'Red Wethers Field' (Bolivia), 'Blood Red Flat' (the Netherlands), 'Brown Beauty'(USA), and 'Yaltinskiy Model No.3' (Russia). Cu showed a low correlation with $\mathrm{Zn}(r=0.24)$ and a very low correlation with Mo $(r=0.028)$. Although $A$. cepa L. is not considered as a valuable source of $\mathrm{Cu}, \mathrm{Fe}, \mathrm{Mn}$, and $\mathrm{Zn}$ for humans (Marles, 2017), knowledge about the accumulation of these elements in onion bulbs is important for optimizing growing conditions by taking genetic characteristics into account.

Mo ensures enzyme catalysis and electron transfer; it is also involved in the synthesis of amino acids and the exchange of vitamins $\mathrm{C}, \mathrm{E}$, and $\mathrm{B} 12$ (Avtsyn et al., 1991). A human's daily Mo requirement is $0.5 \mathrm{mg}$. Mo is mainly accumulated in the liver, kidneys, internal secretion glands, and skin. The Mo content of the cultivar 'Tavricheskiy' from Russia $(6.83 \%$ of weight) was the highest, followed that of eight other onion cultivars $(5.15 \%$ to $6.14 \%$ of weight), i.e., 'Yaltinskiy Model No.3' (Russia), 'Yaltinskiy Rubin' (Russia), 'Mestniy' (Azerbaijan), 'Trimontzium' (Bulgaria), 'Red Wethers Field' (Bolivia), 'Yaltinskiy Lux' (Russia), and 'B1213213' (Australia) (Table 1). A moderate Mo content $(2.68 \%$ to $4.01 \%$ of weight) was found in three onion cultivars, i.e., 'Blood Red Flat' (the Netherlands), 'Rouge Pale' (Algeria), and 'Valensiya' (Portugal), whereas a low Mo content (1.35\% to $1.86 \%$ weight) was discovered in three cultivars, i.e., 'Southport Red' (USA), 'Brown Beauty' (USA), and 'Mestniy' (Russia). However, the cultivar 'Yaltinskiy Model No.5' (Russia) showed the lowest Mo content ( $0.44 \%$ of weight). The variations in the accumulation of Mo in onion cultivars are well managed by varietal characteristics (Nemtinov et al., 2020).

$\mathrm{Zn}$ stabilizes the structure of molecules and plays an important role in DNA and RNA metabolism, protein synthesis, cell division, and signal transmission inside the cell (Nechaev et al., 2007). Plant concentrators and even super-concentrators that can accumulate micronutrients can be used to treat and prevent $\mathrm{Zn}$ deficiency in humans. In this study, the onion cultivar 'Yaltinskiy 
Model No.3' (Russia) showed very high Zn accumulation $(4.97 \%$ of weight), followed by six other cultivars $(0.47 \%$ to $0.82 \%$ of weight), i.e., 'Mestniy' (Russia), 'B1213213' (Australia), 'Rouge Pale' (Algeria), 'Blood Red Flat' (the Netherlands), 'Brown Beauty'(USA), and 'Yaltinskiy Rubin' (Russia) (Table 1). The other seven onion genotypes accumulated low amounts of $\mathrm{Zn}(0.2 \%$ to $0.33 \%$ weight). The lowest $\mathrm{Zn}$ content $(0.07 \%$ to $0.11 \%$ of weight) was found in 'Tavricheskiy' (Russia) and 'Valensiya' (Portugal). Crimean onion bulbs, i.e., 'Yaltinskiy Model No.3' (Russia) and 'Yaltinskiy Rubin' (Russia) had high Zn-Fe $(r=0.84)$ and $\mathrm{Zn}-\mathrm{Cu}(r=0.90)$ correlations. The present results were also consistent with the past findings of Morris (1981) and Nemtinov et al. (2019a, b, 2020) who also explained the differences in the biochemical composition of the onion.

$\mathrm{Si}$ is an obligatory element in plants (Kolesnikov and Gins, 2001). It is accumulated in large quantities in leaves and root conductive tissues. Si does not only work as the basis of tissues, it also controls several biological and chemical processes in humans and animals. The elasticity of the skin, tendons, and vascular walls are mainly managed by Si. $\mathrm{Si}$ increases the plant's specific resistance to abiogenic stresses. In this study, $\mathrm{Si}$ content $(0.5 \%$ of weight) was highest in 'Yaltinskiy Lux' (Russia), moderate $(0.21 \%$ to $0.3 \%$ of weight) in genotypes 'B1213213' (Australia), 'Mestniy' (Azerbaijan), and 'Yaltinskiy Model No.3' (Russia), and low in the remaining 11 cultivars $(0.11 \%$ to $0.2 \%$ of weight). The present results showed that onions accumulated a low amount of Si. This result was consistent with past findings showing that onions are nonaccumulators of Si (Lewin and Reimann, 1969).

\section{Characteristics of onion samples}

The environmental conditions in Crimea, Russia, provide a prolonged period of vegetative growth; average-to-long storage period; and midripening, half spicy, and sweet (salad) onion cultivars. In the present research, 15 onion cultivars belonging to nine countries, including four genotypes from FSBSI 'RIAC', Russia ('Yaltinskiy Rubin', 'Yaltinskiy Lux', 'Yaltinskiy Model No.3', and 'Yaltinskiy Model No.5') were evaluated. The shapes and colors of onion bulbs are the basic factors influencing consumer demand for salad onions. Indeed, onion color indicates the prevailing presence of antioxidants, such as polyphenols, i.e., flavonoids (quercetin) and anthocyanins (Kong et al., 2003; Nuutila et al., 2003; Lu et al., 2011; Cheng et al., 2013; Nemtinov et al., 2019a, b). Therefore, the yellow, white, and light-pink onions of the 10 genotypes from Russia (two samples), the USA (two samples), Australia, Bulgaria, Algeria, Azerbaijan, the Netherlands, and Portugal can be assumed to contain flavonoids (quercetin), whereas brownpurple, dark-purple, and purple onions from Russia ('Yaltinskiy Rubin' and 'Yaltinskiy Model No.3') and Bolivia contain anthocyanins, which are in considerable demand in the onion market (Figure 8).

\section{Biochemical composition of onion bulbs}

Biochemical analysis revealed that the majority of the 13 onion cultivars exceeded the standard values of dry matter concentration and sugars (monoand disaccharides) by $13 \%$ and $46 \%$, $11 \%$ and $48 \%$, and $36 \%$ and $150 \%$ (Table 2). However, two onion cultivars, i.e., 'B1213213' (Australia) and 'Yaltinskiy Model No.3' (Russia) showed lower concentrations of dry matter $(12 \%-19 \%)$, sugars $(2 \%)$, and disaccharides $(22 \%)$ than the standard.

The onion bulbs of the 'Red Wethers Field' (Bolivia), 'Valensiya (Portugal)', and 'Brown Beauty' (USA) showed the highest concentration of total sugars and disaccharides. The monosaccharide and ascorbic acid contents of the onion cultivar 'Yaltinskiy Model No.3' (Russia), were $10 \%$ and $47 \%$ higher than the standard, respectively. 


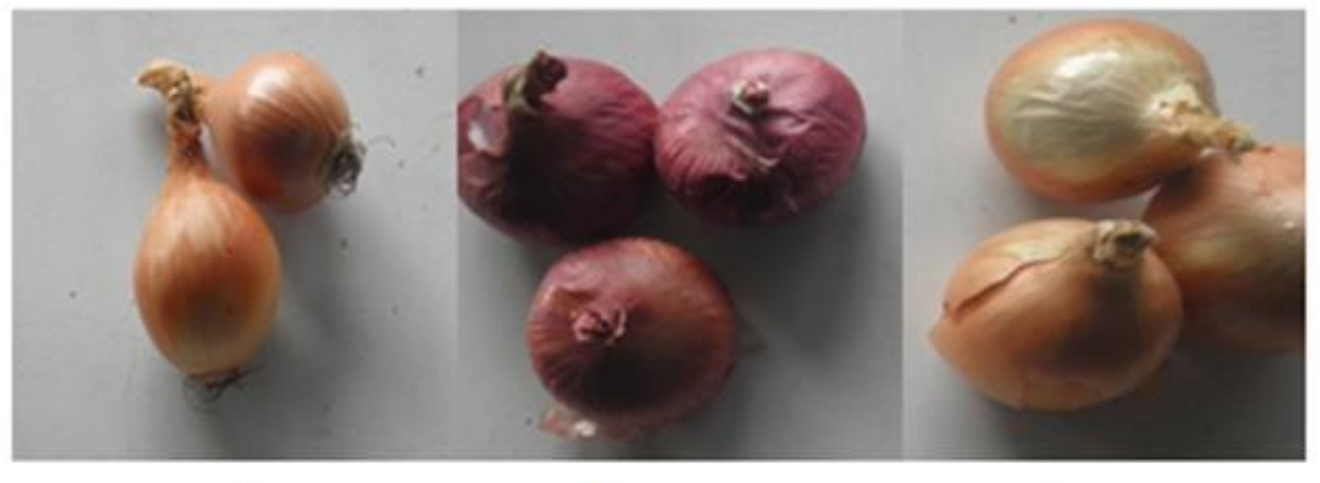

a

b

c

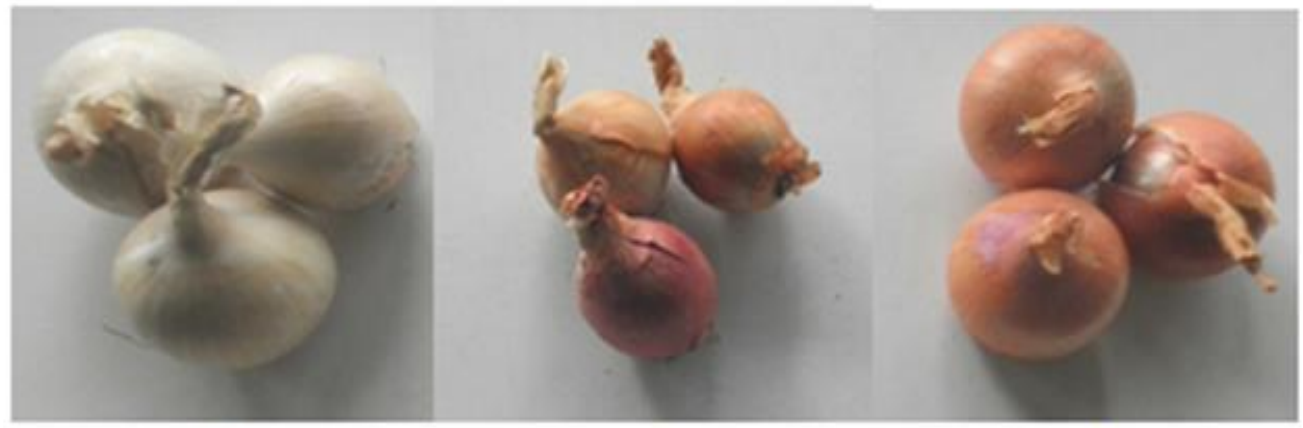

d
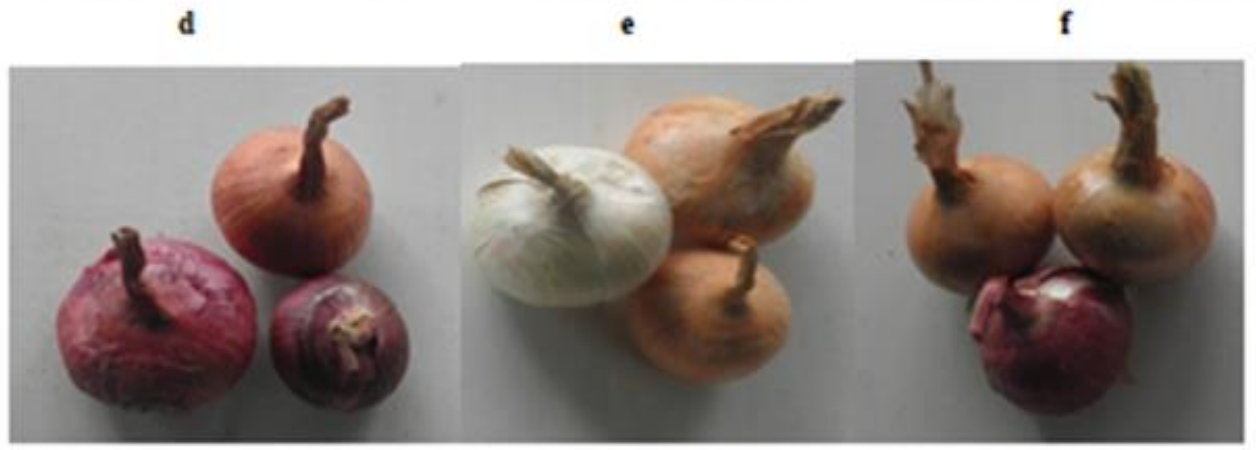

g

h

i

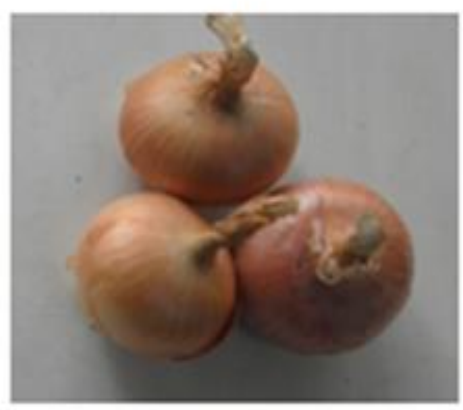

k

Figure 8. Allium cepa L. samples with different colors: A - Mestniy (Russia) - yellow, b Yaltinskiy Rubin (Russia) - purple, c - Southport red (USA) - yellow, d -Trimontzium (Bulgaria) - white, e - Tavricheskiy (Russia) - light-pink, f - Rouge pale (Algeria) - yellow, $g$ - Red Wethers Field (Bolivia) - dark-purple, $\mathrm{h}$ - Blood Red Flat (the Netherlands) yellow, I -Valensiya (Portugal) - yellow, k - Brown Beauty (USA) - yellow. 
Table 2. Biochemical characteristics of Allium cepa L. cultivars, $\bar{X}$ (2016-2017).

\begin{tabular}{lllll}
\hline $\begin{array}{l}\text { Cultivar names and their } \\
\text { origin }\end{array}$ & $\begin{array}{l}\text { Dry solids } \\
(\%)\end{array}$ & $\begin{array}{l}\text { Sugars sum } \\
(\%)\end{array}$ & $\begin{array}{l}\text { Ascorbic acid } \\
(\mathrm{mg} / 100 \mathrm{~g})\end{array}$ & $\begin{array}{l}\text { Essential oil } \\
(\%)\end{array}$ \\
\hline $\begin{array}{l}\text { Yaltinskiy Rubin (Russia) } \\
- \text { control }\end{array}$ & $8.8 \pm 0.61$ & $11.7 \pm 0.98$ & $18.6 \pm 1.20$ & $4.5 \pm 0.03$ \\
Mestniy (Russia) & $10.5 \pm 0.95$ & $13.0 \pm 1.04$ & $11.8 \pm 1.07$ & $2.8 \pm 0.02$ \\
B1213213 (Australia) & $7.7 \pm 0.64$ & $11.4 \pm 0.97$ & $16.6 \pm 1.13$ & $2.8 \pm 0.02$ \\
Southport Red (USA) & $10.0 \pm 0.88$ & $14.4 \pm 0.93$ & $12.9 \pm 0.99$ & $2.8 \pm 0.01$ \\
Trimontzium (Bulgaria) & $11.4 \pm 0.93$ & $14.7 \pm 1.01$ & $16.1 \pm 1.54$ & $1.6 \pm 0.01$ \\
Tavricheskiy (Russia) & $11.5 \pm 0.85$ & $13.2 \pm 0.99$ & $16.2 \pm 1.37$ & $6.2 \pm 0.03$ \\
Rouge Pale (Algeria) & $12.2 \pm 0.97$ & $13.7 \pm 0.95$ & $16.3 \pm 1.05$ & $4.1 \pm 0.02$ \\
Mestniy (Azerbaijan) & $10.8 \pm 0.90$ & $13.6 \pm 0.86$ & $18.6 \pm 1.25$ & $2.7 \pm 0.01$ \\
Red Wethers Field & $10.8 \pm 0.82$ & $17.3 \pm 1.19$ & $21.1 \pm 1.49$ & $4.0 \pm 0.02$ \\
(Bolivia) & & & & \\
Blood Red Flat (the & $10.6 \pm 0.86$ & $12.5 \pm 1.02$ & $19.6 \pm 1.01$ & $5.6 \pm 0.03$ \\
$\begin{array}{l}\text { Netherlands) } \\
\text { Valensiya (Portugal) }\end{array}$ & $11.4 \pm 0.79$ & $16.7 \pm 1.25$ & $16.7 \pm 1.13$ & $4.0 \pm 0.03$ \\
$\begin{array}{l}\text { Brown Beauty (USA) } \\
\text { Yaltinskiy Model No.3 }\end{array}$ & $11.7 \pm 0.82$ & $18.1 \pm 1.14$ & $14.8 \pm 1.10$ & $4.4 \pm 0.03$ \\
(Russia) & $7.1 \pm 0.65$ & $11.3 \pm 0.92$ & $27.3 \pm 1.26$ & $0.9 \pm 0.01$ \\
\hline
\end{tabular}

Note: Means within a column with at least one identical superscript are not significantly different by Student`s ttest $(P<0.05)$.

Gordienko and Tkalenko (2012) reported that genotypes with disaccharide-tomonosaccharide ratios of less than 1.0 are considered sweet onions. In the present evaluation, only two genotypes of 'Yaltinskiy' from Crimea, Russia, had ratios of $0.5-0.7$ and were considered as sweet onions. The highest concentration of ascorbic acid was found in 'Red Wethers Field' (Bolivia, $21.1 \mathrm{mg} / 100 \mathrm{~g}$ ) and 'Yaltinskiy Model No.3' (Russia, 27.3 $\mathrm{mg} / 100 \mathrm{~g}$ ) and was $5 \%$ to $14 \%$ higher than the standard $(18.6 \mathrm{mg} / 100 \mathrm{~g})$.

Caruso et al. (2014) and Nemtinov et al. (2019a, b) reported that sweet onions contain the highest levels of antioxidants and ascorbic acid. Thus, the consumption of $100 \mathrm{~g}$ of fresh sweet onions of two cultivars from Crimea, Russia, can provide $16 \%$ to $39 \%$ of the human daily requirement of vitamin C. The vitamin $C$ contents of the other genotypes varied from $11.8 \mathrm{mg} / 100 \mathrm{~g}$ to $21.1 \mathrm{mg} / 100 \mathrm{~g}$ of fresh bulbs. However, because of their spicy taste, these onion genotypes are consumed after processing. Past studies have shown that the essential oil content of onion cultivars in the range of $0.9 \%$ to $6.2 \%$ which is a basic characteristic of salad onions (Caruso et al., 2014).

\section{Morphological and cytological study of onion leaves}

The electronic-microscopic analysis of 11 onion cultivar leaves allowed the determination of the micromorphological characteristics of the cuticle surface (presence of beams, folds, and wax layer), the characteristics of stomata, length, and number in $1 \mathrm{~mm}^{2}$ of the leaf surface (Table 3).

The highest number of stomata on the adaxial side of leaves was found in the onion cultivars 'B1213213' (Australia), 'Valensiya' (Portugal), 'Tavricheskiy' (Russia), and 'Trimontzium' (Bulgaria) with values of $49.9 \times 10^{2}, 47.4 \times 10^{2}$, $38.9 \times 10^{2}$, and $37.6 \times 10^{2} \mathrm{pcs} / \mathrm{mm}^{2}$, respectively. In the majority of onion genotype samples, the stomata length varied from $8.71 \mu \mathrm{m}$ ('B1213213', Australia) to $22.49 \mu \mathrm{m}$ ('Blood Red Flat', the Netherlands). The largest stomata $(34.32 \mu \mathrm{m})$ were found in the onion 
Table 3. Micro-morphology of the surface of Allium cepa L. genotype leaves.

\begin{tabular}{|c|c|c|c|c|}
\hline \multirow{2}{*}{ Onion cultivars } & \multirow{2}{*}{$\begin{array}{l}\text { Stomata } \\
\text { length }(\mu \mathrm{m})\end{array}$} & \multicolumn{2}{|c|}{ Margin of fluctuation } & \multirow{2}{*}{$\begin{array}{l}\text { Stomata number, } \\
\left(\mathrm{pcs} / 1 \mathrm{~mm}^{2}\right)\end{array}$} \\
\hline & & Min & Max & \\
\hline $\begin{array}{l}\text { Yaltinskiy Rubin (Russia) - } \\
\text { control }\end{array}$ & 34.32 & 28.28 & 38.87 & $32.1 \times 10^{2} \pm 287.4$ \\
\hline Mestniy (Russia) & 26.98 & 20.10 & 34.51 & $19.7 \times 10^{2} \pm 287.3$ \\
\hline B1213213 (Australia) & 18.71 & 16.97 & 19.31 & $49.9 \times 10^{2} \pm 399.8$ \\
\hline Southport Red (USA) & 20.51 & 16.54 & 24.95 & $31.4 \times 10^{2} \pm 474.7$ \\
\hline Trimontzium (Bulgaria) & 20.34 & 16.23 & 22.92 & $37.6 \times 10^{2} \pm 349.8$ \\
\hline Tavricheskiy (Russia) & 19.67 & 16.23 & 25.83 & $38.9 \times 10^{2} \pm 398.4$ \\
\hline Rouge Pale (Algeria) & 27.12 & 23.84 & 29.47 & $25.7 \times 10^{2} \pm 437.3$ \\
\hline Mestniy (Azerbaijan) & 21.15 & 14.96 & 31.23 & $25.5 \times 10^{2} \pm 599.7$ \\
\hline $\begin{array}{l}\text { Red Wethers Field } \\
\text { (Bolivia) }\end{array}$ & 29.15 & 27.46 & 36.54 & $29.6 \times 10^{2} \pm 399.8$ \\
\hline $\begin{array}{l}\text { Blood Red Flat (the } \\
\text { Netherlands) }\end{array}$ & 22.49 & 16.05 & 25.83 & $20.6 \times 10^{2} \pm 274.8$ \\
\hline Valensiya (Portugal) & 27.13 & 24.05 & 32.08 & $47.4 \times 10^{2} \pm 324.8$ \\
\hline Brown Beauty (USA) & 24.92 & 21.56 & 29.92 & $34.9 \times 10^{2} \pm 262.4$ \\
\hline Average & 26.19 & 20.19 & 29.29 & $32.78 \times 10^{2}$ \\
\hline
\end{tabular}
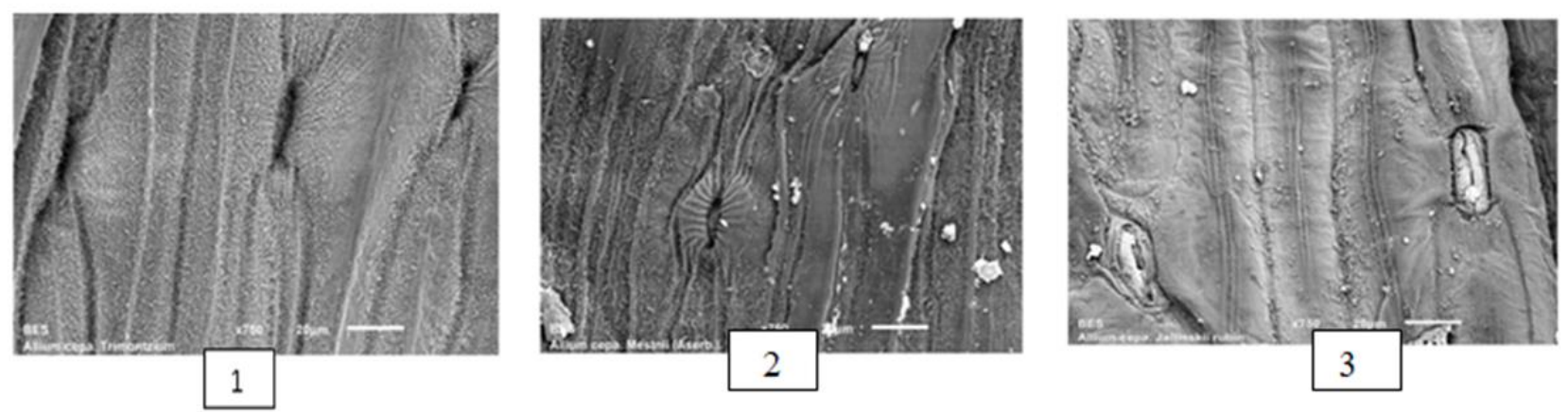

Figure 9. Characteristics of stoma position in $A$. cepa L. cultivars: 1 - Trimontzium (Bulgaria), 2 - Mestniy (Azerbaijan), 3 - Yaltinsky Rubin (Russia).

cultivar 'Yaltinskiy Rubin' (Russia) with nonsignificant stomatal numbers per 1 $\mathrm{mm}^{2}$ of the leaf surface $\left(37.6 \times 10^{2} \mathrm{pcs}\right)$. The structural characteristics of the three basic contrasting cultivars i.e., 'Trimontzium' (Bulgaria), 'Mestniy' (Azerbaijan), and 'Yaltinsky Rubin' (Russia) are presented in Figure 9. The micrographs of the structure of the stomata show the characteristic of $A$. cepa L. and corresponded to the structure obtained by Pacheco-da-Silva et al. (2015). The number of stomata per unit of leaf surface in the studied onion genotypes was greater than in the cultivars described in the past.
The results further revealed that the microstructure of the leaf surface of each onion cultivar was specific. The analysis of the structure of the epidermis of the lower surface of the leaf showed that the stomata of onion genotypes were generally elongated (length greater than width) with clearly visible auxiliary cells of the epidermis and were covered by a wax layer. The stomata were located at different depths of the cuticle surface, i.e., in the cultivar 'Trimontzium' (Bulgaria), the stomata were found below the surface, deep into the cuticle. In the cultivar 'Mestniy' (Azerbaijan), the 
stomata were located above the cuticle surface and had well-developed runs that perhaps guaranteed the improved opening and closing of stomatal pores. In the onion genotype 'Yaltinsky Rubin' (Russia), the stomata were located at the level of the cuticle and had well-developed stomatal rollers. The large length of the stomata (21.15-34.32 $\mu \mathrm{m})$ corresponded to highly productive genotypes with thick cuticles. In general, the stomata of the onion genotypes were elongated (length greater than width) with clearly visible auxiliary cells of the epidermis and were covered by a wax layer (Pacheco-da-Silva et al., 2015; Nemtinov et al., 2019a, b).

\section{CONCLUSIONS}

Concentrator onion cultivars with the highest macro- and microelement concentrations were identified for treatment of nutrient deficiency in humans. Analysis revealed that the highest contents of the elements in the investigated onion cultivars were as follows: $K(20.0 \%$ to $31.3 \%$ of weight) in nine onion cultivars, $P(1.8 \%$ to $2.8 \%$ of weight) in five cultivars, $\mathrm{Mg}(2.23 \%$ of weight) in one cultivar, $\mathrm{Ca}$ ( $5.4 \%$ to $8.3 \%$ of weight) in nine cultivars, $\mathrm{Fe}(0.5 \%$ to $0.8 \%$ of weight) in two cultivars, $\mathrm{S}(2.2 \%$ to $2.5 \%$ of weight) in seven cultivars, $\mathrm{Na}$ ( $1.3 \%$ to $1.5 \%$ of weight) in two cultivars, $\mathrm{Cl}(4.0 \%$ to $7.0 \%$ of weight) in five cultivars, and Mo (5.2 to $7.0 \%$ weight) in eight onion cultivars. Zn was accumulated at high levels ( $4.97 \%$ of weight) in the superconcentrator 'Yaltinskii Model No. 3' (Russia) and at $0.5 \%$ to $0.8 \%$ of weight in six concentrator cultivars. Si was present at the level of $0.5 \%$ of weight in one onion cultivar. The evaluation of the biochemical parameters of onion cultivars with different ecogeographical origins revealed high nutritional values. Moreover, the leaf surface microstructure of onion cultivars was specific, and the largest stomata corresponded to the most productive cultivars.

\section{REFERENCES}

Agafonov AF, Kamaleev KHB, Kononkov PF, Gins MS, Gins VK (2005). Prospects of using onions as a source of biologically active substances. Bull. Acad. Agric Sci. 2: 43-45.

Ananyina MN, Glukhova VM (1988). Peculiarities of the chemical composition of various structures of the bulb parts of Allium cepa L. Scientific and Technical Bulletin of All-Russian Res. Inst. of Plant Industry named after N.I. Vavilov. 180: 50-57.

Avtsyn AP, Zhavoronkov AA, Rishe AA, Strochkova LS (1991). Macro-elements of man: etiology, classification. Organopathology. Medicine, Moscow, Russia.

Błażewicz-Woźniak $M$, Kęsik T, Wach $D$, end Konopiński M (2008). The influence of conservation tillage on mineral elements content in soil and chemical composition of onion. Acta Scien. Polonorum Hortorum Cultus. 7(2): 6172.

Borisenkova LS (1993). Onions and garlic. VIR, St. Peterburg, Russia.

Caruso G, Conti S, Villari G, Borrelli C, Melchionna G, Minutolo M, Russo G, Amalfitano C (2014). Effects of transplanting time and plant density on yield, quality, and antioxidant content of onion (Allium cepa L.) in Southern Italy. Sci. Hort. 166: 111-120.

Cheng A, Chen X, Jin Q, Wang W, Shi J, Liu Y (2013). Comparison of phenolic content and antioxidant capacity of red and yellow onions. Czech J. Food Sci. 31: 501-508.

Chope GA, Terry LA (2009). Use of canonical variate analysis to differentiate onion cultivars by mineral content as measured by ICP-AES. Food Chem. 115: $1108-1113$.

Danikov NI (1998). Onions are a natural healer. Ripol Klassik, Moscow, Russia.

Díaz-Pérez AJC, Bautista J, Gunaw G (2018). Sweet onion (Allium cepa L.) as influenced by organic fertilization rate: 1. Plant growth, and leaf and bulb mineral composition. HortSci. 53 (4): 451-458.

Dudchenko NS (2009). Working out of elements of technology for selection on the raised accumulation of chemical 
elements in vegetable production of long-term bows: Dissertation Abstract, Agric. Sci. VNISSOK, Moscow, Russia.

Fraga CG (2005). Relevance, essentiality, and toxicity of trace elements in human health. Mol. Aspects Med. 26: 235244.

Galkin GA, Sheudzhen AKH, Sheudzhen MA (2000). Onion and garlic: unique curative and preventive properties. Problems of ecology in agriculture and medicine. Communication and Abstracts of the Scientific-Practical Conference. Krasnodar April 20-22, 2000, Maikop, pp. 110-136.

Gins MS, Gins VK (2011). Physiological and biochemical basis of introduction and selection of vegetable cultures. PFUR, Moscow, Russia.

Gins MS, Gins VK, Motyleva SM, Kulikov IM, Medvedev SM, Kononkov PF, Pivovarov VF (2018). Mineral composition of amaranth (Amaranthus L.) seeds of vegetable and grain usage by archives selection. Potravinarstvo Slovak J. Food Sci. 12 (1): 330-336.

Golubkina NA, Agafonov AF, Dudchenko NS (2009). The maintenance of microelements in perennial onions. Gavrish 5: 18-21.

Golubkina NA, Agafonov AF, Nadezhkin SM, Antoshkina MS, Koshevarov AA. (2015). Element composition of Allium cepa L. Vestnik of Ulyanovsk State Agric. Acad. 3: 11-17.

Golubkina NA, Kekina HG, Antoshkina MS, Nadezhkin SM, Agafonov AF (2016). Variety differences in accumulating biologically active combination by common onion Allium cepa L. Vestnik Russian Agric. Sci. 2: 23-29.

Golubkina NA, Nadezhkin SM, Agafonov AF, Antoshkina MS, Koshevarov AA (2015). Soderzhanie iron, manganese, zinc, and copper in onions in the collection of VNIISSOK. Bull. Ulyanovsk State Agric. Acad. 3: 11-16.

Golubkina NA, Pivovarov VF, Nadezhkin SM, Loseva TA, Sokolova AYA (2013). The global ecological crisis. Problems and Solutions. VNIISSOK, Moscow, Russia.

Gordienko IM, Tkalenko GM (2012). Characterization of essential oil of onion varieties Tkachevsky and Mermaid. Vegetable and Melon Growing 58: 104-110.

Jurgiel-Małecka G, Suchorska-Orłowska J (2008). The effect of nitrogen fertilization on the content of microelements in selected onions. $J$. Elementol. 13 (2): 227-234.

Kabata-Pendías A, Pendías H. (2001). Trace elements in soils and plants. $3^{\text {rd }}$ Edition. CRC Press LCL, Boca Raton, USA.

Kalbarczyk R, Kalbarczyk E (2015). The adverse effect of the long-term trend of the air temperature in Poland on the yield of onion. J. Cent. Eur. Agric. 16(1): 41-53.

Kielak E, Grzegorzewska M, Gawronska H (2006). Levels of abscisic acid in the onion during storage and bulb storability as influenced by weather conditions during the growing season and bulb maturity at harvest. Veg. Crops Res. Bull. 64: 51-65.

Kleiber T, Bosiacki M, Markiewicz B (2010). Effect of the controlled fertilization on the mineral components of chosen varieties of onion (Allium cepa L.). Part II. Microelements and sodium. Ecol. Chem. Eng. A. 17 (8): 935-941.

Kolesnikov MP, Gins VK (2001). Forms of silicon in medicinal plants. Appl. Biochem. Microbiol. J. 37 (5): 524527.

Kong JM, Chia LS, Goh NK, Chia TF, Brouillard $R$ (2003). Analysis and biological activities of anthocyanins. Phytochem. 64 (5): 923-933.

Lewin J, Reimann BEF (1969). Silicon and Plant Growth. Annu. Rev. Plant Physiol. 20: 289-304.

Lu X, Wang J, Hamzaf M, Ross CF, Powers JR, Tang J, Rasco BA (2011). Determination of total phenolic content and antioxidant capacity of onion and shallots using infrared spectroscopy. Food Chem. 129: 637-644.

Marles RJ. (2017). Mineral nutrient composition of vegetables, fruits, and grains: The context of reports of apparent historical declines. J. food comp. Anal. 56: 93103.

Meathnis FGM, Ichida AM, Sanders D, Schroeder JI (1997). Roles of higher plant K+ channels. Plant Physiol. 114(4): 1141-1149.

Morris EA, Witkind WM, Dix RL, Acobson JJ (1981). Nutritional content of selected aboriginal foods in northeastern colorado; buffalo (Bison Bison) and wild onions (Allium SPP). J. Ethnobiol. 1(2): 213-220.

Motyleva SM, Kulikov IM, Marchenko LA (2017). EDS analysis for fruit Prunus elemental composition determination. 
Mat. Sci. Forum Trans. Tech. Pub. Ltd., 888: 314-318.

Nechaev AP, Trauberg SE, Kochetkova AA (2007). Food chemistry. GIORD, St. Peterburg, Russia.

Nemtinov $V$, Golubkina N, Koshevarov A, Kostanchuk $Y$, Molchanova A, Nadezhkin S, Michele Sellito V, Caruso G (2019a). Health-beneficial compounds from edible and waste bulb components of sweet onion genotypes organically grown in Northern Europe. J. Biotechnol. Banat. 19: 58.

Nemtinov V, Kostanchuk Y, Motyleva S, Timasheva L, Pekhova O, Kulikov I, Medvedev S, Bokhan A (2019b). The field and laboratory study of the collected samples of onion breed Allium cepa L. Potravinarstvo Slovak J. Food Sci. 13(1): 58-64.

Nemtinov VI, Kostanchuk YN, Motyleva SM, Katskaya AG, Timasheva LA, Pekhova OA, Pashtetskiy VS, Kulikov IM, Medvedev SM, Bokhan AI. (2020). Mineral composition of Allium cepa L. leaves of Southern subspecies. Potravinarstvo Slovak J. Food Sci. 14(1): 216-223.

Nuutila AM, Puupponen-Pimia R, Aarni M, Oksman-Caldentey K (2003). Comparison of antioxidant activities of onion and garlic extracts by inhibition of lipid peroxidation and radical scavenging activity. Food Chem. 4 (81): 485-493.

Pacheco da Silva VC, Bettoni MM, Bona C, Foerste LA (2015). Morphological and chemical characteristics of onion plants (Allium cepa L.) associated with resistance to onion thrips. Acta Sci. Agron. 37 (1): 85-92.

Peter K, Gandhi P (2017). Rediscovering the therapeutic potential of Amaranthus species: A review. Egyptian J. Basic Appl. Sci. 4(3): 196-205.

Platonova IE (2000). The healing bow. RESPEKT, St. Peterburg, Russia.

Randle WM (2000). Increasing nitrogen concentration in hydroponic solutions affects onion flavor and bulb quality. $J$. Am. Soc. Hort. Sci. 125: 254-259.

Rodrigues GB, Oropeza GR, Rodrigues RE, Diaz RC. (2008). Comparison of mineral and trace element contents in onion cultivars (Allium cepa L.). J. Sci. Food Agric. 88: 1554-1561.

Schoenbl H, Ziegler H (1977). The mechanism of stomatal movements in Allium cepa L. Plant 136: 37-43.

Seredin TM., Gerasimova LI., Kozar EG., Agafonov AF., Soldatenko AV., Krivenkov LV. (2017). Correlation analysis of accumulation among different chemical elements in bulbs of winter garlic (Allium sativum L.). Vegetable Crops of Russia 1: 6770.

Skalnaya MG, Dubovoi RM, Skalny AV (2004). Chemical elements - micronutrients as a reserve for restoring the health of Russian citizens. RIK GOU OGU, Orenburg, Russia.

Skurikhin IM, Tutelyan VA (2007). Tables of the chemical composition and caloric content of Russian food. DeLi print, Moscow, Russia.

Timasheva LA, Pekhova OA, Danilova IL (2018). Methodology for the chamazulene determination in the raw material of Achillea millefolium L. Taurida herald Agrarian Sci. 3(15): 119-125.

Tosin AT, Adekale AI, Wohab AG (2017). Evaluation of the nutritional composition and Antioxidant properties of onion (Allium Cepa) and garlic (Allium Sativum). Int. J. Sci. Tech. Sci. 5(10): 1-6.

Ulyanova TN (1998). Healing properties of onion. Peter, St. Peterburg, Russia.

Vodyanova OS, Alpysbaeva VO (2004). Onions: Textbook. Aleiron, Almati, Kazakhstan.

WHO (2012). Guideline: Potassium intake for adults and children. World Health Organization. Geneva, Switzerland.

Yoldas F, Ceylan S, Nand M, Esetlili BC (2011). Effect of organic and inorganic fertilizers on yield and mineral content of onion (Allium cepa L.). Afr. J. Biotechnol. 10(55): 11488-11492.

Yunus MM. Mineral Contents of (Allium cepa) Red and White Onions Grown around Gashu'a Fadama Area (2016). Int. J. Sci. Glob. Sustain. 2 (2): 94-99. 